\title{
Bacterial remediation of heavy metal polluted soil and effluent from paper mill industry
}

\author{
Uloma Linda Nwaehiri', Peter Ikechukwu Akwukwaegbu² ${ }^{2}$, Bertram Ekejiuba Bright Nwoke ${ }^{3}$ \\ 'Department of Environmental Biology, Federal Polytechnic Nekede, Owerri, Nigeria; ${ }^{2}$ Department of Biochemistry, University of Port Harcourt, Choba, \\ Nigeria; ${ }^{3}$ Department of Animal and Environmental Biology, Imo State University, Owerri, Nigeria
}

\begin{abstract}
Bacterial remediation of heavy metal polluted soil and effluent from paper mill was investigated using standard analytical methods. The paper mill was visited for 6 months at interval of 30 days to collect soil and effluent samples for the analysis. The $\mathrm{pH}$ of soil was slightly alkaline while effluent was acidic. There was a significant increase $(P<0.05)$ in total organic carbon (TOC) of soil; and turbidity, biochemical oxygen demand (BOD), chemical oxygen demand (COD) and TOC of effluent when compared to control. Bacteria isolated from the samples were grouped into two and used to remediate eight heavy metals. The remediation experiment consists of three treatments; Treatment 1 (treated with proteobacteria), Treatment 2 (treated with non-proteobacteria) and Treatment 3 (without bacteria) (control experiment). Result of the remediation study showed that there was a significant decrease $(P<0.05)$ in Treatment 1 and Treatment 2 of all the heavy metals in soil and effluent samples from day 30-180 when compared to day 0 . The rate of removal of heavy metals in soil was highest in Treatment 1 for chromium $\left(\mathrm{Cr}_{0} 0.00846\right.$ day $\left.^{-1}\right)$ and lowest in Treatment 1 for cadmium $\left(\mathrm{Cd} ; 0.00403\right.$ day $\left.^{-1}\right)$ while the rate of removal in effluent was highest in Treatment 1 for zinc $\left(\mathrm{Zn} ; 0.01207\right.$ day $\left.^{-1}\right)$ and lowest in Treatment 1 for $\mathrm{Cd}(0.00391$ day $\left.^{-1}\right)$. It was concluded that bacteria isolated from soil and effluent samples were capable of remediating the concentration of $\mathrm{Pb}$, arsenic (As), Cr, Zn and nickel (Ni) heavy metals.
\end{abstract}

Keywords: Remediation, Heavy metals, Soil, Effluent, Proteobacteria, Non-protobacteria, Rate of removal

\section{Introduction}

Heavy metals exist in concentrations that vary in nature or as a direct consequence of the activities of man within the ecosystem [1]. In recent times, anthropogenic activities of man introduced some of these heavy metals into the environmental soil and water bodies beyond acceptable limits [2]. According to Awofolu [3], heavy metals are translocated through food chain; however they could be toxic at certain concentrations owing to their non-degradable nature. The limiting factor about heavy metals is their inability to be broken down and their toxicity to living organisms at stipulated levels. To ensure the general safety of the environment to man and living organisms, polluted soil and water bodies should be remediated to rid of heavy metals and other minute elements [4].

There are numerous techniques that ranges from oxidation/

Received: Mar 28, 2019 Accepted: May 23, 2019

Corresponding author: Peter Ikechukwu Akwukwaegbu

University of Port Harcourt Choba, 38 Nwafor Street Orji, Owerri, Imo State,

Nigeria

E-mail: peter_akwukwaegbu@uniport.edu.ng

This article is available from: http://e-eht.org/ reduction, precipitation, evaporation, filtration, ion exchange, electrochemical and osmotic methods utilized to take away heavy metals from contaminated environment [5]. The major shortfall of the aforementioned techniques is their inability to remove heavy metals at concentrations below $100 \mathrm{mg} / \mathrm{L}$ [6] and the solubility of salts formed by these heavy metals [7] coupled with their expensive and fluctuating nature. To eliminate these shortcomings, the use of biological methods such as bioremediation using microbes and plants has emerge as an effective and safe technique for the remediation of soil and water bodies contaminated with heavy metal [8].

Bioremediation is an innovative technology that has gained wide recognition for elimination of heavy metals from contaminated soil and water bodies. Owing to the variation in survival strategies by microbes to contaminated environments, these microbes resort to different means of adaption such as biosorption, biodigestion, bioaccumulation, biomineralization and biotransformation to detoxify heavy metals either in-situ or ex-situ [4,9-12]. The uptake of heavy metals by microbes can either be by adsorption (passive) or bioaccumulation (active) [13]. However, presence of heavy metals in the 
soil and water bodies brings about certain modifications in the microbial community [14] which can be expressed via blockage and inhibition of vital functional moieties, modifications of active molecules or displacement of metal $[4,15]$. Bacterial cell wall consists of polysaccharides, proteins and lipids which offer binding capacity to amino, phosphate, carboxylate and hydroxyl groups of heavy metals $[4,16]$.

\section{Methods}

\section{Sample collection}

The method of Neboh et al. [17] was employed for collection of soil and effluent sample. The paper mill was visited for 6 months at interval of 30 days to collect samples during the period and samples were collected in the morning hours during the peak activities between 9:00-11:00 am. The soil samples were excavated at $45 \mathrm{~cm}$ depth for optimal bacteria action using a soil auger and collected with the aid of aluminum foils for organic chemical analysis while effluent samples were collected using $500 \mathrm{~mL}$ sterilized Pyrex glass bottles with tight screw stoppers. All samples were replicated thrice, transported to the laboratory in ice jackets and processed within 6 hours after sampling. The bacterial species was isolated and heavy metals concentration and potential of the isolated bacteria to bioremediate contaminated soil and effluent discharge were analyzed.

\section{Isolation of bacterial and grouping}

\section{Isolation}

For isolation of bacteria in soil samples, exactly $10 \mathrm{~g}$ of the soil was mixed in $90 \mathrm{~mL}$ deionized water while for bacteria isolation in effluent samples, $10 \mathrm{~mL}$ of the effluent were diluted in $90 \mathrm{~mL}$ of deionized water [18]. The mixture was placed in an automated orbital shaker (Searchtech Nig Ltd) at $180 \mathrm{rpm}$ for 3 hours to shake vigorously, and the resulting suspension was subjected to 10 times serial dilution. Aliquots $(0.1 \mathrm{~mL})$ each of $\left(10^{-2}, 10^{-3}, 10^{-4}\right.$ or $\left.10^{-5}\right)$ of the test tubes were dispensed under aseptic condition into nutrient agar plate by spread plate technique and incubated at $37^{\circ} \mathrm{C}$ for 24 hours on the incubator. After incubation, developed colonies were further sub-cultured to obtain pure samples before identification and grouping.

\section{Grouping}

The bacteria species were identified based on biochemical characteristics as described in literatures [19-21]. Bacteria isolated and identified were grouped into proteobacteria and non-proteobacteria according to their proton charge.
Soil and effluent digestion for heavy metal analysis in paper mill

Digestion and analysis of soil samples

Ten grams of the soil sample was placed into $50 \mathrm{~mL}$ beaker and $5 \mathrm{~mL}$ of concentrated aqua-regia $\left(\mathrm{HNO}_{3}: \mathrm{HCl}_{2} \mathrm{H}_{2} \mathrm{SO}_{4}\right.$ in the ratio of 3:2:1) was added. The mixture in the beakers were covered with watch glass and boiled on a hot plate at $125^{\circ} \mathrm{C}$ for 2 hours. A small portion of aqua-regia was added to the solution and it appeared light color and clear. The beaker wall and watch glass were then washed with deionized water and the samples was filtered to remove insoluble materials that could clog the atomizer. Then, the digest was cooled at room temperature and filtered through a Whatman Grade 1 filter paper in $50 \mathrm{~mL}$ volumetric flask. The volume of the filtrate was made up to $50 \mathrm{~mL}$ with deionized water.

\section{Digestion of effluent sample}

$5 \mathrm{~mL}$ of $\mathrm{HNO}_{3}$ was added to $50 \mathrm{~mL}$ of water sample and digested by heating on a plate to obtain a colorless solution. The digest was cooled down and then filtered into a $100 \mathrm{~mL}$ volumetric flask. The volume of the digested water sample was made up to $100 \mathrm{~mL}$ with distilled water [22].

A control sample was digested by transferring $50 \mathrm{~mL}$ of deionized water into a beaker and digesting as described above for blank correction. Heavy metals, $\mathrm{Cu}^{2+}(324 \mathrm{~nm}), \mathrm{Zn}^{2+}(213$ $\mathrm{nm}), \mathrm{Fe}^{2+},(248 \mathrm{~nm}), \mathrm{Cr}^{2+}(357 \mathrm{~nm}), \mathrm{Cd}(228 \mathrm{~nm}), \mathrm{As}(193 \mathrm{~nm})$, $\mathrm{Ni}(232 \mathrm{~nm})$, and $\mathrm{Pb}^{2+}(283 \mathrm{~nm})$ were determined directly at the stated wavelengths on each final solution using classical Atomic Absorption Spectroscopy (Model: PG-990 AAS) [22]. Results obtained were compared with Federal Environmental Protection Agency (FEPA) [23] Standard.

Formulation of microbial consortium for bioremediation of heavy metals in contaminated soil and effluent

The utilized microbial consortia in this study comprised isolated strains using the method stated above. First, individual strains were grown in Nutrient Agar for 2 days at $33^{\circ} \mathrm{C}$, inoculated to Nutrient Broth and grown to achieve stationary phase in an automated orbital shaker at $150 \mathrm{rpm}$. Upon achieving a growth of $1.3 \mathrm{ABS}$ at a wavelength of $600 \mathrm{~nm}$, the individual strains were pooled out in equal amounts [9].

\section{Experimental design}

Bioremediation study was carried out using the method of Fauziah et al. [18] Contaminated (within the paper mill environment) and uncontaminated (a control point outside the paper mill polluted site) soil and water samples were utilized for the bioremediation study. The experiment consists of three 
treatments; Treatment 1 treated with proteobacteria, Treatment 2 treated with non-proteobacteria and Treatment 3 without bacteria (control experiment). A $2 \mathrm{~g}$ of contaminated soil/2 $\mathrm{mL}$ of effluent was amended with $10 \%(\mathrm{v} / \mathrm{v})$ of microbial inoculum. Each treatment was made up of $3 \times 10^{9} \mathrm{CFu} / \mathrm{mL}$ of inoculums. The experimental set up lasted for 6 months and readings taken at interval of 30 days. Water was added regularly to keep the moisture level at $60-65 \%$. The process was replicated thrice for all treatments.

\section{Rate equation for the removal of heavy metal}

The rate of heavy metal uptake per day was obtained according to the equation of first order kinetic models [18]:

$$
K=-\frac{1}{t}\left(\operatorname{In} \frac{C}{C_{o}}\right)
$$

where $K$ is the constant for first order rate of heavy metal uptake per day, $t$ is time (days), $C$ is concentration of residual metal in the soil per effluent $(\mathrm{L} / \mathrm{kg})$, and $\mathrm{C}_{0}$ is initial concentration of metal in the soil/effluent $(\mathrm{L} / \mathrm{kg})$

\section{Method of Data analysis}

Data were analyzed using Statistical package for Biological and Social Sciences (SPSS) Incident 21.0 Software. Descriptive and one-way analysis of variance (ANOVA) for comparison was carried out and results expressed as mean \pm standard deviation.

\section{Results and Discussion}

\section{Analysis of Physicochemical Parameters of Contaminated Soil and Effluent Samples}

The physicochemical analyses of contaminated and effluent samples are shown in Tables 1 and 2, respectively.

\section{Biochemical test}

The biochemical identification of bacteria isolated from pol-

Table 1. Physicochemical parameters of contaminated soil sample

\begin{tabular}{|c|c|c|c|}
\hline Parameters & Control $(n=3)$ & Contaminated soil $(n=3)$ & FEPA Limit 1999 [23] \\
\hline $\mathrm{pH}$ & $6.51 \pm 0.70$ & $7.30 \pm 1.10$ & $6.50-8.50$ \\
\hline Conductivity ( $\mu S / \mathrm{cm})$ & $50.00 \pm 17$ & $120.00 \pm 11^{*}$ & 1000.00 \\
\hline Calcium (mg/kg) & $5.05 \pm 1.20$ & $12.62 \pm 3.97^{*}$ & 200.00 \\
\hline Magnesium (mg/kg) & $8.89 \pm 2.10$ & $10.08 \pm 2.96$ & 50.00 \\
\hline Total organic carbon (\%) & $5.32 \pm 4.24$ & $12.08 \pm 3.96^{*}$ & 5.00 \\
\hline Total nitrogen (\%) & $0.49 \pm 0.03$ & $0.63 \pm 0.04^{*}$ & - \\
\hline Phosphate (mg/kg) & $1.20 \pm 0.30$ & $1.20 \pm 0.40$ & 5.00 \\
\hline Total chloride (mg/kg) & $105.97 \pm 9.44$ & $89.97 \pm 6.26$ & 250.00 \\
\hline
\end{tabular}

${ }^{*} p<0.05$

Table 2. Physicochemical parameters of effluent samples

\begin{tabular}{lccc}
\hline Parameters & Control $(\mathrm{n}=3)$ & Effluent samples $(\mathrm{n}=3)$ & FEPA Limit 1999 [23] \\
\hline Temperature $\left({ }^{\circ} \mathrm{C}\right)$ & $28.6 \pm 0.80$ & $29.80 \pm 1.30$ & $20-30$ \\
Odour & Unobjectionable & Objectionable & Unobjectionable \\
Appearance & Clear & Very turbid & Clear \\
Colour $(\mathrm{PCU})$ & $13.00 \pm 3.50$ & $160.00 \pm 25.00^{*}$ & 15.0 \\
$\mathrm{pH}$ & $4.6 \pm 0.02$ & $4.96 \pm 0.02$ & $6.50-8.50$ \\
Conductivity $(\mu \mathrm{S} / \mathrm{cm})$ & $140.00 \pm 8.00$ & $800.00 \pm 85.00^{*}$ & 1000.00 \\
Turbidity $(\mathrm{NTU})$ & $1.67 \pm 0.30$ & $47.40 \pm 5.74^{*}$ & 10.00 \\
Total dissolved solid $(\mathrm{mg} / \mathrm{L})$ & $91.00 \pm 4.50$ & $520.00 \pm 20.00^{*}$ & 500.00 \\
Total solids $(\mathrm{mg} / \mathrm{L})$ & $112.00 \pm 8.20$ & $8876.00 \pm 126.50^{*}$ & $500.00-1500.00$ \\
Total suspended solid $(\mathrm{mg} / \mathrm{L})$ & $9.00 \pm 3.80$ & $7356.00 \pm 168.80^{*}$ & $<10.00$ \\
Total hardness CaCO ${ }_{3}(\mathrm{mg} / \mathrm{L})$ & $43.90 \pm 3.86$ & $54.09 \pm 32.60^{*}$ & 150 \\
BOD $(\mathrm{mg} / \mathrm{L})$ & $0.20 \pm 0.00$ & $86.40 \pm 8.40^{*}$ & 0.00 \\
COD $(\mathrm{mg} / \mathrm{L})$ & $0.32 \pm 0.01$ & $8377.40 \pm 156.45^{*}$ & 0.00 \\
Total chloride $(\mathrm{mg} / \mathrm{L})$ & $129.96 \pm 9.66$ & $189.00 \pm 7.65^{*}$ & 250.00 \\
Nitrate $(\mathrm{mg} / \mathrm{L})$ & $21.70 \pm 3.77$ & $117.70 \pm 11.30^{*}$ & 45.00 \\
Calcium $(\mathrm{mg} / \mathrm{L})$ & $10.93 \pm 2.45$ & $16.00 \pm 1.10^{*}$ & 10.00 \\
Phosphate $(\mathrm{mg} / \mathrm{L})$ & $0.90 \pm 0.30$ & $100.84 \pm 10.22^{*}$ & 5.00 \\
Magnesium(mg/L) & $2.96 \pm 0.40$ & $204.93 \pm 32.05^{*}$ & 50.00 \\
Total organic carbon $(\%)$ & $4.07 \pm 2.20$ & 5.00
\end{tabular}

${ }^{*} p<0.05$

PCU, platinum cobalt unit, NTU, nephelomentry turbidity unit; BOD, biochemical oxygen demand; COD, chemical oxygen demand. 
Table 3. Biochemical identification of bacteria isolated from polluted soil samples

\begin{tabular}{|c|c|c|c|c|c|c|c|c|c|c|c|c|c|c|c|c|}
\hline $\begin{array}{l}\text { Sample } \\
\text { code }\end{array}$ & & & & & & & & TSIA & & & & & & & & \\
\hline & Catalase & Motility & $\begin{array}{l}\text { Methyl } \\
\text { red }\end{array}$ & VP & Citrate & Oxidase & Coagulase & Glucose & Fructose & Slant & Butt & $\mathrm{H} 2 \mathrm{~S}$ & Gas & $\begin{array}{l}\text { Gram } \\
\text { stain }\end{array}$ & Microscopic & Bacteria \\
\hline 1) & + & + & + & - & + & + & - & + & - & B & B & - & - & - & Long rod & $\begin{array}{l}\text { Pseudomonas } \\
\text { pyogenes }\end{array}$ \\
\hline 2) & + & - & + & - & + & + & + & + & + & A & A & - & - & - & $\begin{array}{l}\text { Cocci in } \\
\text { cluster }\end{array}$ & $\begin{array}{l}\text { Staphylococcus } \\
\text { aureus }\end{array}$ \\
\hline 3) & + & + & - & + & + & - & - & + & + & $A$ & A & + & + & - & Rod & Erwnia amylovora \\
\hline 4) & + & + & - & + & + & - & + & + & + & A & A & + & + & - & Rod & Enterobacter cloacae \\
\hline 5) & + & + & + & - & + & + & - & + & - & B & B & - & - & + & Rod & Bacillus subtilis \\
\hline 6) & + & + & - & + & + & - & - & - & - & B & A & + & + & - & Rod & Serratia marcescens \\
\hline
\end{tabular}

A, Acidic condition; B, Basic condition; +, positive; -, negative; VP, Vogas proskauer test; H2S, hydrogen sulfide; TSIA, triple sugar ion agar.

Table 4. Biochemical identification of bacteria isolated from effluent samples

\begin{tabular}{|c|c|c|c|c|c|c|c|c|c|c|c|c|c|c|c|c|}
\hline $\begin{array}{c}\text { Sample } \\
\text { code }\end{array}$ & & & & & & & & TSIA & & & & & & & & \\
\hline & Catalase & Motility & $\begin{array}{c}\text { Methyl } \\
\text { red }\end{array}$ & VP & Citrate & Oxidase & Coagulase & Glucose & Fructose & Slant & Butt & $\mathrm{H} 2 \mathrm{~S}$ & Gas & $\begin{array}{l}\text { Gram } \\
\text { stain }\end{array}$ & Microscopic & Bacteria \\
\hline 1) & + & + & + & - & - & - & - & + & - & B & A & - & - & - & Rod & Acinetobacter baumannii \\
\hline 2) & + & + & + & - & + & - & - & + & + & A & A & - & + & - & Rod & Citrobacter freundii \\
\hline 3) & + & + & - & + & + & - & - & + & + & A & A & + & + & - & Rod & Erwnia amylovor \\
\hline 4) & + & + & - & + & + & - & - & + & + & A & A & + & + & - & Rod & Erwnia amylovora \\
\hline 5) & + & + & + & - & - & - & - & + & + & A & A & + & + & - & Rod & Escherichia coli \\
\hline 6) & - & + & - & + & + & - & - & + & + & B & A & + & - & + & Cocci & Streptococcus pneumoniae \\
\hline
\end{tabular}

A, Acidic condition; B, Basic condition; +, positive; -, negative; VP, Vogas proskauer test; H2S, hydrogen sulfide; TSIA, triple sugar ion agar.

Table 5. Grouping of bacteria for bioremediation in soil

\begin{tabular}{lc}
\hline Treatment 1 & Treatment 2 \\
\hline Serratia marcescens & \\
Pseudomonas pyogenes & Bacillus subtilis \\
Erwnia amylovora & Staphylococcus aureus \\
Enterobacter cloacae & \\
\hline
\end{tabular}

luted soil and effluent samples are shown in Tables 3 and 4, respectively.

\section{Bacteria grouping}

The groupings of bacteria for remediation in soil and effluent are shown in Tables 5 and 6, respectively.

\section{Bioremediation of heavy metals in contaminated soil from paper mill industry}

The remediation of heavy metals in contaminated soil is shown in Table 7.

\section{Bioremediation of heavy metals in effluent from paper mill industry}

The remediation of heavy metals in effluent discharge is shown in Figures 1-8.
Table 6. Grouping of bacteria for bioremediation in effluent samples

\begin{tabular}{lc}
\hline Treatment 1 & Treatment 2 \\
\hline Escherichia coli & \\
Acinetobacter baumannii & Streptococcus pneumoniae \\
Erwnia amylovora & \\
Citrobacter freundii & \\
\hline
\end{tabular}

Rate of heavy metals removal from paper mill contaminated soil and effluent

The rate of removal of heavy metals from soil and effluent samples are shown in Tables 8 and 9.

Table 1 contains the results of the physicochemical parameters of contaminated soil sample. There was no significant difference $(\mathrm{P}<0.05)$ in $\mathrm{pH}$ and phosphate of the contaminated soil sample when compared to the control. However, the $\mathrm{pH}$ of contaminated soil was slightly alkaline. There was a significant increase $(\mathrm{P}<0.05)$ in the conductivity, calcium, total organic carbon (TOC) and total nitrogen content when compared to control. The TOC was higher than FEPA [23] limit. Due to limited research on the physicochemical analysis of soil samples from paper mill industries, comparisons were made to the physicochemical parameters of tannery industry and other closely related industries. The obtained $\mathrm{pH}$ values were similar to the findings of Rabah and Ibrahim [24] but dis- 
Table 7. Remediation of heavy metals in contaminated soil across time with different treatments

\begin{tabular}{|c|c|c|c|c|c|c|c|c|}
\hline \multirow{2}{*}{ Parameters } & \multicolumn{7}{|c|}{ Heavy metal concentrations (mg/L; $n=3$ ) } & \multirow{2}{*}{$\begin{array}{l}\text { FEPA Limit } \\
1999 \text { [23] }\end{array}$} \\
\hline & Day 0 & Day 30 & Day 60 & Day 90 & Day 120 & Day 150 & Day 180 & \\
\hline \multicolumn{9}{|l|}{ Lead $(\mathrm{Pb})$} \\
\hline Treatment 1 & $1.223 \pm 0.16$ & $0.398 \pm 0.12^{*}$ & $0.324 \pm 0.06^{*}$ & $0.390 \pm 0.05^{\star}$ & $0.346 \pm 0.05^{\star}$ & $0.312 \pm 0.03^{*}$ & $0.311 \pm 0.01^{*}$ & \multirow[t]{3}{*}{0.05} \\
\hline Treatment 2 & $1.223 \pm 0.12$ & $0.472 \pm 0.04^{*}$ & $0.491 \pm 0.05^{\star}$ & $0.486 \pm 0.03^{\star}$ & $0.494 \pm 0.02^{*}$ & $0.422 \pm 0.01^{*}$ & $0.401 \pm 0.00^{\star}$ & \\
\hline Treatment 3 & $0.025 \pm 0.01$ & $0.021 \pm 0.01$ & $0.022 \pm 0.00$ & $0.020 \pm 0.00$ & $0.022 \pm 0.00$ & $0.025 \pm 0.02$ & $0.022 \pm 0.00$ & \\
\hline \multicolumn{8}{|l|}{ Cadmium (Cd) } & \multirow{4}{*}{0.05} \\
\hline Treatment 1 & $0.093 \pm 0.04$ & $0.062 \pm 0.03^{*}$ & $0.057 \pm 0.03^{*}$ & $0.056 \pm 0.02^{*}$ & $0.045 \pm 0.02^{*}$ & $0.046 \pm 0.01^{*}$ & $0.045 \pm 0.01^{*}$ & \\
\hline Treatment 2 & $0.093 \pm 0.030$ & $0.059 \pm 0.020^{\star}$ & $0.052 \pm 0.020^{*}$ & $0.047 \pm 0.020^{*}$ & $0.042 \pm 0.030^{*}$ & $0.044 \pm 0.030^{*}$ & $0.043 \pm 0.020^{\star}$ & \\
\hline Treatment 3 & N.D & N.D & N.D & N.D & N.D & N.D & N.D & \\
\hline \multicolumn{8}{|l|}{ Arsenic (As) } & \multirow{4}{*}{0.20} \\
\hline Treatment 1 & $0.613 \pm 0.22$ & $0.198 \pm 0.07^{\star}$ & $0.167 \pm 0.03^{\star}$ & $0.166 \pm 0.02^{*}$ & $0.165 \pm 0.01^{*}$ & $0.164 \pm 0.03^{\star}$ & $0.168 \pm 0.00^{\star}$ & \\
\hline Treatment 2 & $0.613 \pm 0.08$ & $0.228 \pm 0.03^{*}$ & $0.217 \pm 0.02^{*}$ & $0.224 \pm 0.02^{*}$ & $0.211 \pm 0.01^{*}$ & $0.208 \pm 0.00^{*}$ & $0.207 \pm 0.00^{\star}$ & \\
\hline Treatment 3 & $0.030 \pm 0.01$ & $0.032 \pm 0.02$ & $0.031 \pm 0.02$ & $0.030 \pm 0.00$ & $0.030 \pm 0.01$ & $0.028 \pm 0.01$ & $0.029 \pm 0.00$ & \\
\hline \multicolumn{8}{|l|}{ Chromium (Cr) } & \multirow{4}{*}{0.05} \\
\hline Treatment 1 & $0.358 \pm 0.11$ & $0.115 \pm 0.02^{*}$ & $0.106 \pm 0.02^{*}$ & $0.098 \pm 0.02^{*}$ & $0.088 \pm 0.00^{*}$ & $0.079 \pm 0.02^{*}$ & $0.078 \pm 0.00^{*}$ & \\
\hline Treatment 2 & $0.358 \pm 0.04$ & $0.156 \pm 0.02^{*}$ & $0.158 \pm 0.01^{*}$ & $0.141 \pm 0.01^{\star}$ & $0.123 \pm 0.00^{\star}$ & $0.126 \pm 0.01^{*}$ & $0.122 \pm 0.00^{*}$ & \\
\hline Treatment 3 & $0.048 \pm 0.01$ & $0.047 \pm 0.02$ & $0.048 \pm 0.01$ & $0.052 \pm 0.01$ & $0.048 \pm 0.01$ & $0.041 \pm 0.01$ & $0.048 \pm 0.02$ & \\
\hline \multicolumn{8}{|l|}{ Zinc (Zn) } & \multirow{4}{*}{0.05} \\
\hline Treatment 1 & $13.169 \pm 2.43$ & $4.740 \pm 0.48^{\star}$ & $4.072 \pm 0.37^{\star}$ & $4.104 \pm 0.26^{*}$ & $3.926 \pm 0.18^{*}$ & $3.776 \pm 0.27^{\star}$ & $3.740 \pm 0.05^{\star}$ & \\
\hline Treatment 2 & $13.169 \pm 1.80$ & $5.726 \pm 0.22^{\star}$ & $5.271 \pm 0.19^{\star}$ & $5.016 \pm 0.23^{*}$ & $4.461 \pm 0.15^{\star}$ & $4.482 \pm 0.21^{*}$ & $4.438 \pm 0.08^{\star}$ & \\
\hline Treatment 3 & $1.420 \pm 0.08$ & $1.366 \pm 0.04$ & $1.362 \pm 0.05$ & $1.363 \pm 0.04$ & $1.352 \pm 0.03$ & $1.350 \pm 0.03$ & $1.350 \pm 0.02$ & \\
\hline \multicolumn{8}{|l|}{ Nickel (Ni) } & \multirow{4}{*}{0.02} \\
\hline Treatment 1 & $0.059 \pm 0.03$ & $0.028 \pm 0.02^{*}$ & $0.025 \pm 0.01^{*}$ & $0.021 \pm 0.01^{*}$ & $0.019 \pm 0.01^{*}$ & $0.017 \pm 0.01^{*}$ & $0.013 \pm 0.00^{*}$ & \\
\hline Treatment 2 & $0.059 \pm 0.02$ & $0.036 \pm 0.02^{*}$ & $0.032 \pm 0.02^{*}$ & $0.028 \pm 0.01^{*}$ & $0.027 \pm 0.01^{\star}$ & $0.022 \pm 0.01^{*}$ & $0.020 \pm 0.01^{\star}$ & \\
\hline Treatment 3 & N.D & N.D & N.D & N.D & N.D & N.D & N.D & \\
\hline \multicolumn{8}{|l|}{ Copper (Cu) } & \multirow{4}{*}{0.10} \\
\hline Treatment 1 & $1.756 \pm 0.46$ & $0.944 \pm 0.03^{*}$ & $0.822 \pm 0.02^{*}$ & $0.832 \pm 0.02^{*}$ & $0.811 \pm 0.02^{*}$ & $0.797 \pm 0.04^{*}$ & $0.774 \pm 0.00^{\star}$ & \\
\hline Treatment 2 & $1.756 \pm 0.27$ & $0.815 \pm 0.02^{*}$ & $0.784 \pm 0.03^{*}$ & $0.733 \pm 0.02^{*}$ & $0.722 \pm 0.02^{*}$ & $0.718 \pm 0.08^{\star}$ & $0.713 \pm 0.00^{\star}$ & \\
\hline Treatment 3 & N.D & N.D & N.D & N.D & N.D & N.D & N.D & \\
\hline
\end{tabular}

${ }^{*} p<0.05$.

ND, Not Detected

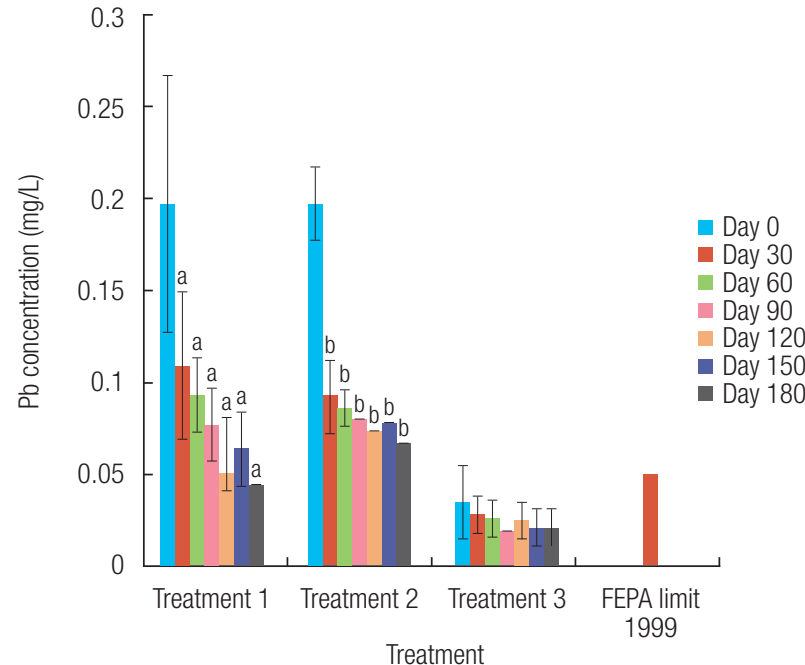

Figure 1. Concentration of lead $(\mathrm{Pb})$ in effluent within the time duration with different treatment $(n=3) .{ }^{*} p<0.05$.

similar to Oluyemi [25] while the concentration of calcium and magnesium obtained were higher than a literature [24] on the physicochemical characterization of soils laden with tan-

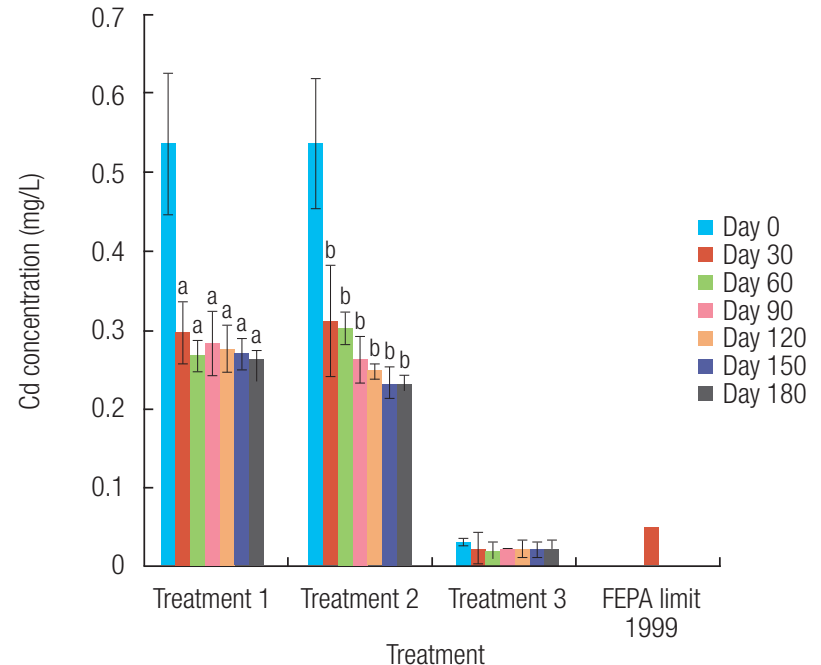

Figure 2. Concentration of cadmium $(\mathrm{Cd})$ in effluent within the time duration with different treatment $(n=3) .{ }^{*} p<0.05$.

nery effluents. The TOC and total nitrogen obtained in the contaminated soil sample were lower than values recorded in Olyuemi [25]. 
Table 2 expressed the results of the physicochemical parameters of effluent sample. The temperature of the effluent discharge was within acceptable range when compared to the limit of FEPA [23]. It was observed that the total suspended solids (TSS), phosphate, colour change, conductivity, turbidity, total dissolved solids, biochemical oxygen demand (BOD), chemical oxygen demand (COD), nitrate and TOC were significantly higher $(\mathrm{P}<0.05)$ in the effluent than both the control and the FEPA limit [23]; however the $\mathrm{pH}$ was lower in the effluent discharge. The acidic $\mathrm{pH}$ value recorded do not fall within the recommended range which is suitable for aquatic life, though the $\mathrm{pH}$ value recorded here is similar to findings of Suryan and Ahluwalia [26] in their work on the maximum adsorption affinity during the biosorption of heavy metals by paper mill waste from aqueous solution. $\mathrm{pH}$ expresses the quality of water and shows the extent of pollution [27], thus the acidic values at the discharge point suggests that the effluents could be harmful and does not support aquatic life as most of their metabolic activities are $\mathrm{pH}$ dependent [28]. Temperature is an essential factor as it controls behavioural characteristics of organisms, solubility of gases and salts in water [29]. The mean temperature value was within the range for a tropical aquatic system $\left(<40^{\circ} \mathrm{C}\right)$ and within FEPA standard [23]. This could be because the effluent was not from thermal pollution or a power plant [30].

High BOD and COD values obtained could be attributed to the high organic matter in the effluent and this connotes toxicity of the effluent discharge [31]. The BOD and COD values obtained in this study were lower than values obtained by Dauda et al. [32]. The greater the BOD, the more rapidly oxygen is depleted in the stream. Both COD and BOD values are a measure of the relative oxygen that is lost from contaminated waste [33].

At high turbidity levels, water loses its ability to support diversity of aquatic organism due to obstruction of light [34]. The high turbid nature of the effluent implies low penetration of light which does not support life and accounts for the corresponding increase in color and conductivity of the effluent.

The TSS level was higher when compared to results obtained by Dauda et al. [32]. Such elevated value for TSS might be attributed to the high organic load and total dissolved solid wastes originating from industrial waste generation. High TSS obstructs light from getting underneath vegetation which slows photosynthesis [35].

Nitrate concentration expresses the quantity of organic matter present mostly as a result of breakdown of protein and nitrogenous compounds [36]. Nitrate at toxic limits cannot be acted upon in the human intestine hence obstructs move- ment in the red blood cells [36]. When compared with the works of Oladeji [37] and Umunnakwe [38], the concentration of nitrates obtained here was higher.

Biochemical identification revealed that Pseudomonas, Staphylococcus, Erwnia, Enterobacter, Bacillus and Serratia species (Table 3) were found in polluted soil and Acinobacter, Citrobacter, Erwnia, Escherichia coli and Streptococcus species (Table 4) were found in the effluent.

The bioremediation studies of the removal of the individual heavy metal in the contaminated soil and effluent samples from paper mill industry for six months are shown in Table 7 and Figures 1-8, respectively. Microorganisms, through different influx and efflux methods alongside metal complexation, are able to reduce and contain heavy metals in soil and effluent samples. Bacteria obtained from contaminated soil and effluent samples were grouped into proteobacteria (Treatment 1) and non-proteobacteria (Treatment 2) according to their gram staining for the bioremediation experiment set up (Tables 5,6) while the third group (Treatment 3) had no bacteria. Proteobacteria are gram negative while non-proteobacteria are gram positive [18]. The bacteria were grouped to enhance metabolic activity of the microbes and increase their affinity to heavy metals [39]. It aids their electrostatic interaction, exchange of ions and redox processes $[40,41]$. Furthermore, grouping of bacteria increases their stability and makes them ideal for field application $[42,43]$.

Table 7 showed the heavy metal remediation on soil samples across time with different treatments. Treatment 1 reduced $74.5 \%$ of extractable $(\mathrm{Pb})$ from the contaminated soil while Treatment 2 reduced $\mathrm{Pb}$ concentration by $67.2 \%$. Treatment 2 (53.8\%) had a higher cadmium (Cd) removal from the contaminated soil than Treatment 1 (51.6\%). Arsenic (As) concentration in soil from was better remediated with Treatment 1 (72.6\%) than Treatment 2 (66.1\%). Treatment 1 (78.2\%) had a higher chromium (Cr) removal from the contaminated soil than Treatment 2 (65.8\%). Treatment 1 (71.6\%) had a higher zinc $(\mathrm{Zn})$ removal than Treatment $2(66.3 \%)$ from the contaminated soil. Treatment 1 removed $78.1 \%$ of the nickel (Ni) from the contaminated soil while Treatment 2 removed $65.3 \%$. Treatment $2(59.4 \%)$ had a higher copper $(\mathrm{Cu})$ removal from the contaminated soil than Treatment 1 (55.9\%). Iron (Fe) was not detected in the soil sample.

There was a significant decrease $(P<0.05)$ in the concentrations of all the heavy metals from day $30-180$ by Treatments 1 and 2 when compared to their respective concentrations at day 0 while Treatment 3 was unchanged. The significant decrease observed in this study might imply that the bacteria have an undiscovered and unexplored potential to remediate 


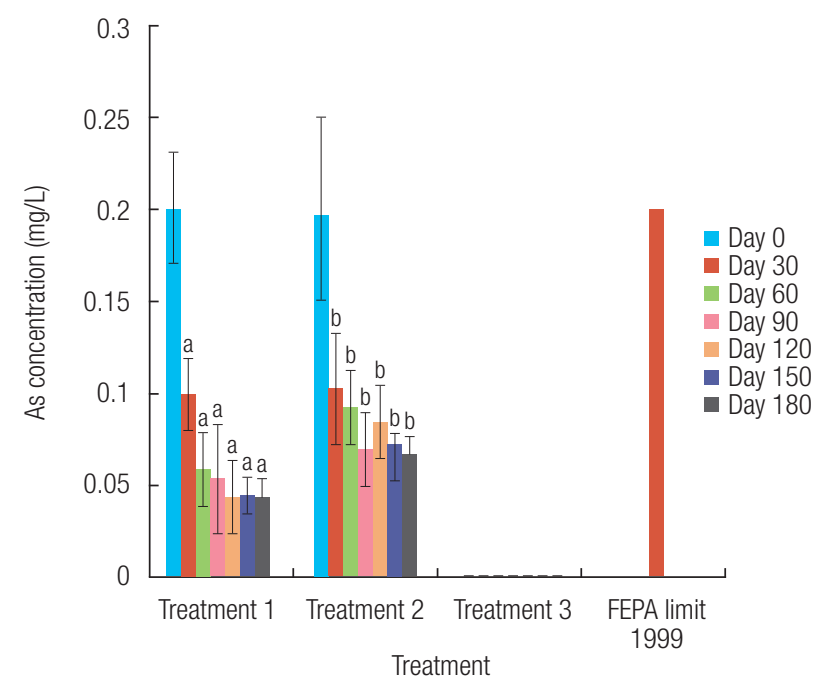

Figure 3. Concentration of arsenic (As) in effluent within the time duration with different treatment $(n=3) .{ }^{*} p<0.05$

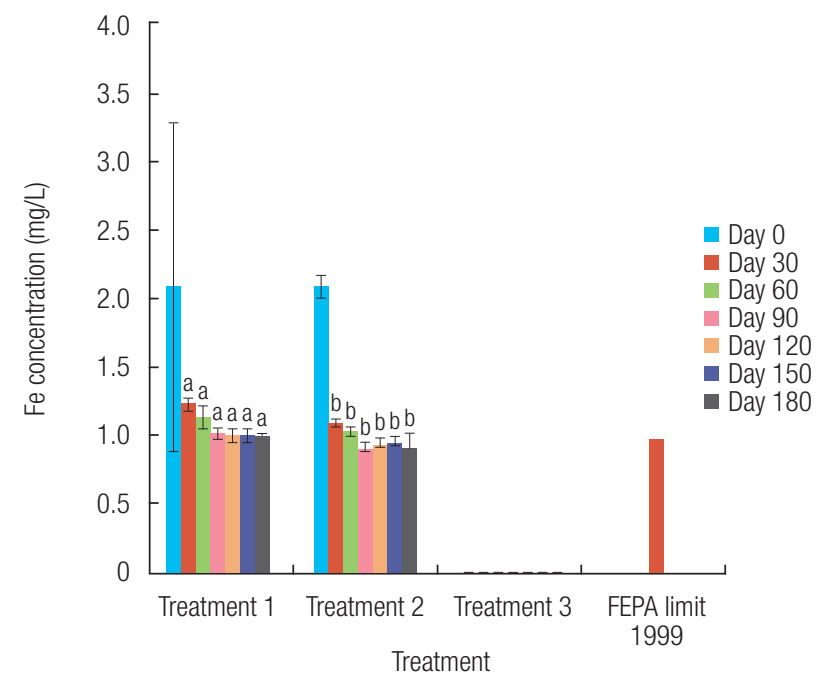

Figure 4. Concentration of iron (Fe) in effluent within the time duration with different treatment $(n=3) .{ }^{*} p<0.05$.

heavy metals in the soil.

Furthermore, Figures 1-8 showed the remediation of heavy metals in effluent samples from day 0-180 with the different treatments. There was a significant decrease $(\mathrm{p}<0.05)$ in the concentrations of all the heavy metals from day 30-180 by Treatments 1 and 2 when compared to their respective concentrations at day 0 while Treatment 3 remained unchanged. Treatment 1 (77.7\%) demonstrated higher removal for $\mathrm{Pb}$ than Treatment 2 (65.8\%) after remediation (Figure 1). Treatment 1 removed 50.5\% of the Cd while Treatment 2 removed 56.4\% from the effluent samples (Figure 2). Treatment 1 (78.5\%) had a higher As removal than Treatment 2 (67.2\%) (Figure 3).

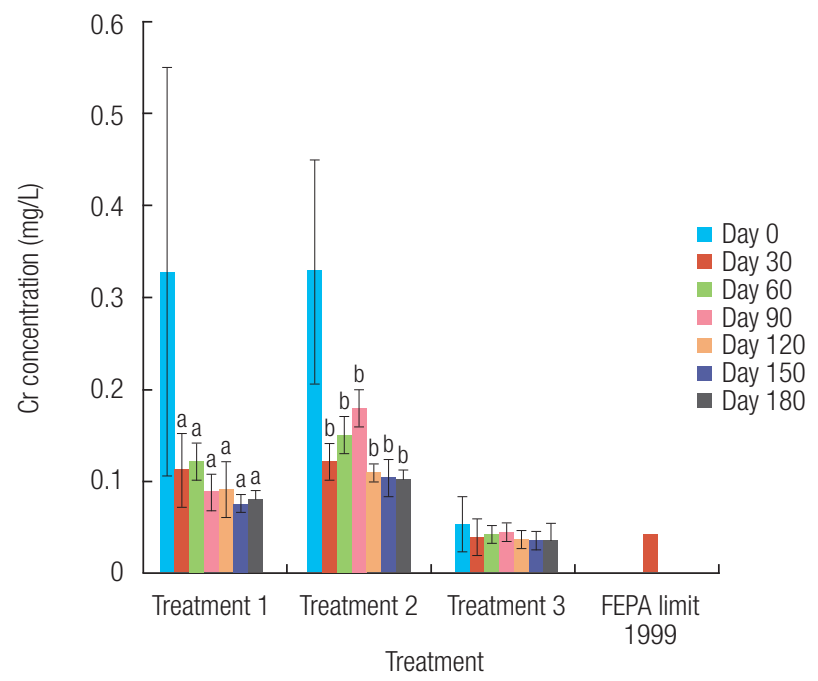

Figure 5. Concentration of chromium (Cr) in effluent within the time duration with different treatment. $(n=3)$. ${ }^{*} p<0.05$.

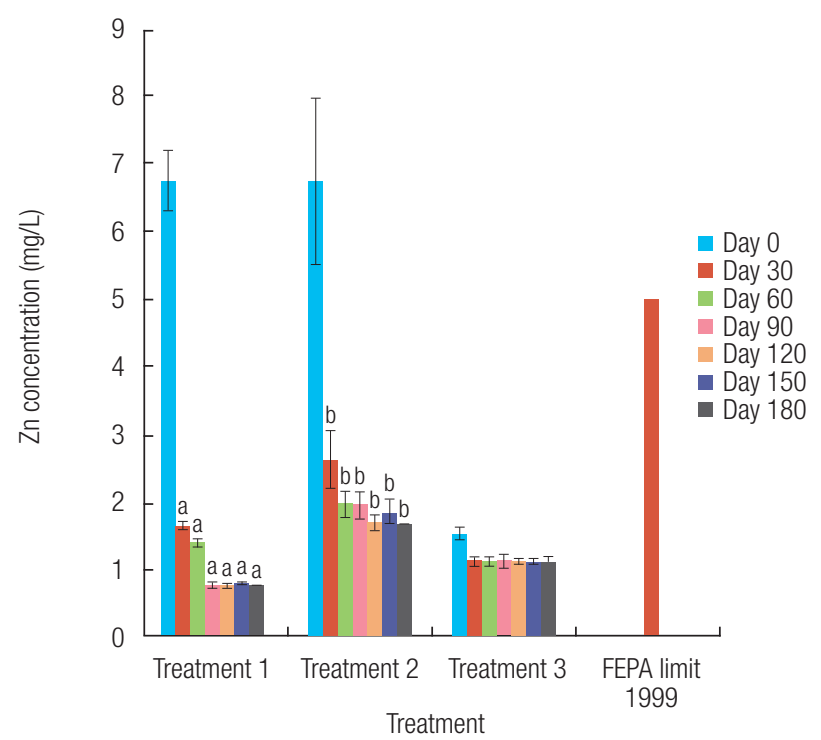

Figure 6. Concentration of zinc $(Z n)$ in effluent within the time duration with different treatment $(n=3) .{ }^{*} p<0.05$.

Higher removal activities were observed with Treatment 2 (56.4\%) than Treatment 1 (51.8\%) for Fe (Figure 4). Treatment 1 removed $74.7 \%$ of Cr while Treatment 2 removed $67.3 \%$ (Figure 5). Figure 6 showed that Treatment 1 (88.6\%) had a higher Zn removal from the effluent sample than Treatment 2 (75.2\%). Treatment $1(79.4 \%)$ had a better Ni metal removal than Treatment 2 (68.4\%) (Figure 7) while Figure 8 expressed higher removal potential of $\mathrm{Cu}$ by Treatment 1 (53.4\%) than Treatment 2 (62.7\%) from the effluent samples. The removal activities for As, $\mathrm{Zn}$ and $\mathrm{Ni}$ in soil and effluent samples were very high when compared to similar study by Fauziah et al. [18] who investigated remediation of heavy metal contaminat- 


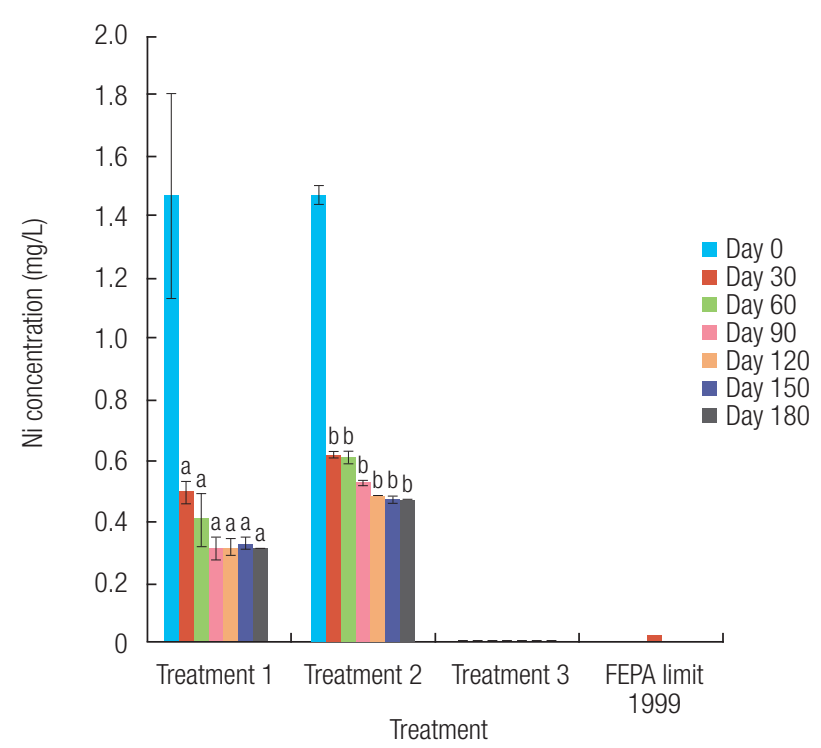

Figure 7. Concentration of nickel (Ni) in effluent within the time duration with different treatment $(n=3)$. ${ }^{*} p<0.05$.

Table 8. Rate of removal of heavy metals from soil per day

\begin{tabular}{lcc}
\hline Heavy metals & Treatment 1 & Treatment 2 \\
\hline $\mathrm{Pb}$ & 0.00759 & 0.00619 \\
$\mathrm{Cd}$ & 0.00403 & 0.00429 \\
$\mathrm{As}$ & 0.00719 & 0.00601 \\
$\mathrm{Cr}$ & 0.00846 & 0.00596 \\
$\mathrm{Zn}$ & 0.00699 & 0.00604 \\
$\mathrm{Ni}$ & 0.00840 & 0.00588 \\
$\mathrm{Cu}$ & 0.00455 & 0.00501 \\
\hline
\end{tabular}

ed soil using potential microbe isolated from a closed dump site. Treatment 1 (Proteobacteria group) generally had higher remediation tendency and appeared to be associated positively with heavy metal removal.

The variation in the removal of heavy metal by the individual treatment groups may be attributed to the fact that certain microbes have higher affinity and sensitivity to a particular heavy metal than another. Microbiological processes in the soil can either solubilize metals (i.e., increase their bioavailability and potential toxicity), or immobilize them, (i.e. decrease the bioavailability of metals). These biotransformation processes are important components of biogeochemical cycles of metals exploited in bioremediation of heavy metal contaminated samples [9].

According to Kuddus et al. [44], bioremediation successfully takes place when $65 \%$ or more of the heavy metals are removed from the original molecule. From this study, it implies that the remediation of $\mathrm{Pb}, \mathrm{As}, \mathrm{Cr}, \mathrm{Zn}$, and $\mathrm{Ni}$ in soil and effluent samples in this study was very successful.

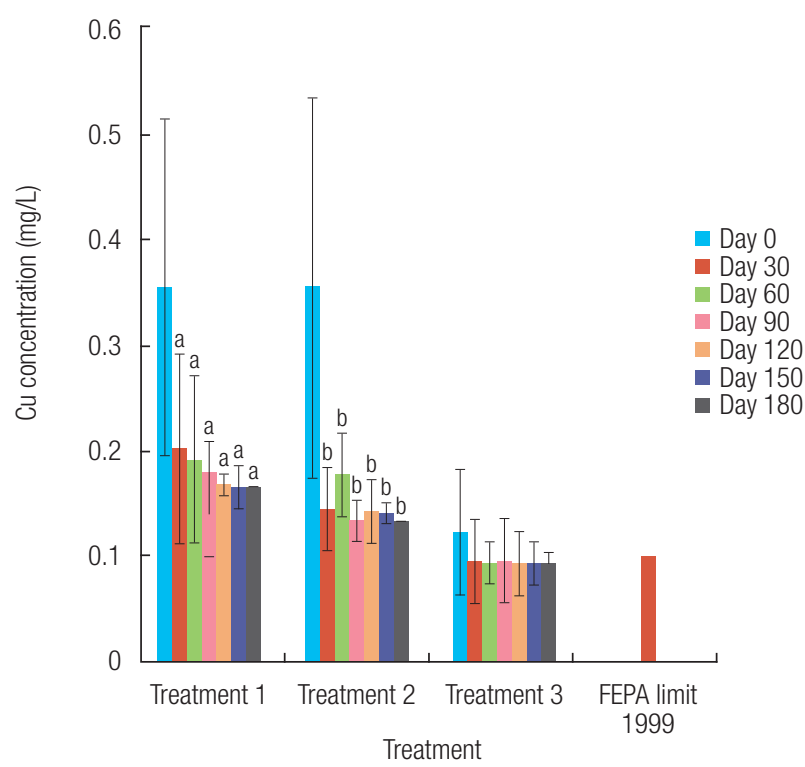

Figure 8. Concentration of copper (Cu) in effluent within the time duration with different treatment $(n=3)$. ${ }^{*} p<0.05$.

Table 9. Rate of removal of heavy metals from effluent samples per day

\begin{tabular}{lcc}
\hline Heavy metals & Treatment 1 & Treatment 2 \\
\hline $\mathrm{Pb}$ & 0.00833 & 0.00599 \\
$\mathrm{Cd}$ & 0.00391 & 0.00463 \\
$\mathrm{As}$ & 0.00854 & 0.00616 \\
$\mathrm{Fe}$ & 0.00405 & 0.00462 \\
$\mathrm{Cr}$ & 0.00764 & 0.00619 \\
$\mathrm{Zn}$ & 0.01207 & 0.00775 \\
$\mathrm{Ni}$ & 0.00877 & 0.00640 \\
$\mathrm{Cu}$ & 0.00424 & 0.00548 \\
\hline
\end{tabular}

The rate of removal of selected heavy metals from soil and effluent samples are shown in Tables 8 and 9. Table 8 showed that for Treatment $1, \mathrm{Cr}\left(0.00846 \mathrm{day}^{-1}\right)$ had the highest removal rate, followed by $\mathrm{Ni}\left(0.00840\right.$ day $\left.^{-1}\right)$, while $\mathrm{Cd}\left(0.00403\right.$ day $\left.^{-1}\right)$ had the least removal rate. For Treatment $2, \mathrm{~Pb}\left(0.00619\right.$ day $\left.^{-1}\right)$ had the highest removal rate, followed by $\mathrm{Zn}\left(0.00604\right.$ day $\left.^{-1}\right)$ while $\mathrm{Cd}\left(0.00429 \mathrm{day}^{-1}\right)$ had the least removal rate. Similarly, $\mathrm{Zn}$ had the highest removal rate for Treatment 1 (0.01207 day1) and Treatment $2\left(0.00775 \mathrm{day}^{-1}\right)$, followed by Ni Treatment 1 $\left(0.00877\right.$ day $\left.^{-1}\right)$ and Treatment $2\left(0.00640\right.$ day $\left.^{-1}\right)$ while Cd Treatment $1\left(0.00391\right.$ day $\left.^{-1}\right)$ and Treatment $2\left(0.00463\right.$ day $\left.^{-1}\right)$ had the least removal rate (Table 9). Generally, Treatment 1 had a higher rate of removal for $\mathrm{Pb}, \mathrm{As}, \mathrm{Cr}, \mathrm{Zn}$, and $\mathrm{Ni}$ in contaminated soil and effluent samples than Treatment 2 . This implies that proteobacteria has higher tendency to remediate most heavy metals in contaminated soil and effluent. The findings from this study on removal rate for heavy metals are similar to other studies on the bioremediation of heavy metal contaminated 
areas $[18,45,46]$ but dissimilar to study by Suryan [26].

\section{Conclusion}

This study has shown that some bacteria have the tendency to survive and transform heavy metals to be less toxic. Though, the soil and effluent discharge were not pretreated, this study has showed that bacteria isolated from paper mill were capable of sorbing the highly toxic heavy metal accumulation in a manner that was time dependent. Heavy metals, $\mathrm{Pb}, \mathrm{As}, \mathrm{Cr}$, $\mathrm{Zn}$, and $\mathrm{Ni}$, in soil and effluent samples were successfully remediated with proteobacteria having a higher remediating potential than non-proteobacteria. This may possibly be the most suitable waste management process in paper mills. The application of this method in a continuous system, microbial bioaccumulation of heavy metals and molecular characterization are among the future research plan.

\section{Conflict of interest}

The authors declare no conflict of interest.

\section{CRediT author statement}

ULN: Conceptualization, Methodology, Software, Validation, Investigation, Resources, Writing-Original, Writing - Review \& Editing, Visualization, Supervision, Project Administration, Funding Acquisition; PIA: Methodology, Software, Formal analysis, Investigation, Writing-Original, Writing-Review \& Editing, Visualization, Project Administration; BEBN: Conceptualization, Validation, Writing-Review \& Editing, Visualization, Supervision.

\section{References}

1. Olayiwola HA, Abudulawal L, Adewuyi GK, Azeez MO. Heavy metal contents in soil and plants at dumpsites: a case study of Awotan and Ajakanga dumpsite Ibadan, Oyo State, Nigeria. J Environ Earth Sci 2017;7(4):11-24

2. Oluyemi EA, Feuyit GJ, Oyekunle AI, Ogunfowokan AO. Seasonal variations in heavy metal concentrations in soil and some selected crops at a landfill in Nigeria. Afr J Environ Sci Technol 2008;2(5):8996.

3. Awofolu OR. A survey of trace metals in vegetation, soil and lower animal along some selected major roads in metropolitan city of Lagos. Environ Monit Assess 2005;105(1-3):431-447.

4. Dixit R, Malaviya D, Pandiyan K, Singh UB, Sahu A, Shukla R, et al. Bioremediation of heavy metals from soil and aquatic environment: an overview of principles and criteria of fundamental processes. Sustainability 2015; 7(2):2189-2212.
5. Gupta A, Joia J, Sood A, Sood R, Sidhu C, Kaur G. Microbes as potential tool for remediation of heavy metals: a review. J Microb Biochem Technology 2016;8(4):364-372.

6. Ahluwalia SS, Goyal D. Microbial and plant derived biomass for removal of heavy metals from wastewater. Bioresour Technol 2007; 98(12):2243-2257.

7. Hussein H, Moawad H, Farag S. Isolation and characterization of Pseudomonas resistant to heavy metals contaminants. Arab J Biotechnol 2004;7(1):13-22.

8. Kapoor A, Viraraghvan T. Fungal biosorption-An alternative treatment option for heavy metal bearing wastewater: A review. Bioresour Technol 1995;53(3):195-206.

9. Gadd GM. Bioremedial potential of microbial mechanisms of metal mobilization and immobilization. Curr Opin Biotechnol 2000;11(3): 271-279.

10. Lim PE, Mak KY, Mohamed N, Noor AM. Removal and speciation of heavy metals along the treatment path of wastewater in subsurfaceflow constructed wetlands. Water Sci Technol 2003;48(5):307-313.

11. Malik A. Metal bioremediation through growing cells. Environ Int 2004;30(2):261-278.

12. Lin CC, Lin HL. Remediation of soil contaminated with the heavy metal (Cd2 $2^{+}$. J Hazard Mater 2005;122(1-2):7-15.

13. Abou-Elela SI. Interaction of the different heavy metal ions with immobilized bacterial culture degrading xenobiotic wastewater compounds. In Proceedings of the Second International Water Association World Water Conference, Berlin, Germany; 2001, p. 15-19.

14. Jansen E, Michels M, van Til M Doelman P. Effects of heavy metals in soil on microbial diversity and activity as shown by the sensitivity-resistance index, an ecologically relevant parameter. Biol Fertil Soils 1994;17:177-1784.

15. Li F, Tan TC. Monitoring BOD in the presence of heavy metal ions using a poly (4-vinylpyr-idine) coated microbial sensor. Biosens Bioelectron 1994;9(6):445-455.

16. Scott JA, Karanjkar AM. Repeated cadmium biosorption by regenerated Enterobacter aerogenes biofilm attached to activated carbon. Biotechnol Lett 1992;14:737-740.

17. Neboh HA, Ilusanya OA, Ezekoye CC, Orji FA. Assessment of IjebuIgbo Abattoir effluent and its impact on the ecology of the receiving soil and river. J Environ Sci Toxicol Food Technol 2013;7(5):61-67.

18. Fauziah SH, Jayanthi B, Emenike CU, Agamuthu C. Remediation of heavy metal contaminated soil using potential microbes isolated from a closed disposal site. Int J Biosci Biochem Bioinform 2017;7(4):230237.

19. Cheesbrough M. Biochemical tests to identify bacteria. In: Laboratory practice in tropical countries.Cambridge: Cambridge university press; 2002, p. 36-70

20. Holt JG. Bergery manual of determinative bacteriology. 9th ed. Philadelphia: Lippincott Williams and Wilkins; 1994, p. 40-350.

21. Koeman MD, Stephen DA. Diagnostic Microbiology. 3rd ed. Philadelphia: Lippooincot Williams and Wilkins; 1998, p. 557-582.

22. Olafisoye BO, Adefisoye T, Osibote OA. Heavy metals contamination of water, soil, and plants around an electronic waste dumpsite. Pol J Environ Stud 2013;22(5):1431-1439.

23. Federal Environmental Protection Agency (FEPA). Guidelines and standard for environmental pollution control in Nigeria. Federal Ministry of Environment Publications; 1999, p.206. 
24. Rabah AB, Ibrahim ML. Physico-chemical and microbiological characterization of soils laden with tannery effluents in Sokoto, Nigeria. Niger J Basic Appl Sci 2010;18(1):65-71.

25. Oluyemi OF. Microbiological and physicochemical assessment of poultry soil samples in Akure Metropolis, Nigeria. Int J Environ Agric Res 2016;2(12):2454-1850.

26. Suryan S, Ahluwalia SS. Biosorption of heavy metals by paper mill waste from aqueous solution. Int J Environ Sci 2012;2(3):1331-1343.

27. Jonnalagadda SB, Mhere G. Water quality of the Odzi River in the Eastern Highlands of Zimbabwe. Water Res 2001;35(10):2371-2376.

28. Chen JC, Lin CY. Responses of oxygen consumption, Ammonia-N excretion and Urea-N excretion of Penaeus chinensis exposed to ambient ammonia at different salinity and pH levels. Aquac 1995;136(34):243-255.

29. Joanne MW, Linda MS, Christopher JW. Influences of environmental factor on growth. In: Prescott's Microbiology. 8th Ed. New York: McGraw Hill International Edition; 2011, p. 177-178.

30. Ram SL, Pravin US, Deepali SP. Pollution in Water of Kasardi River flowing along Taloja Industrial Area of Mumbai, India. World Environ 2011;1(1):6-13.

31. Chukwu O, Ajisegiri ESA, Onifade KR, Jimoh OD. Environmental impact auditing of food processing industry in Nigeria: the case of climate and air quality. AU J.T. 2007;11(2):77-85.

32. Dauda DR, Duro D, IJah UJJ. Physicochemical and microbiological qualities of the abattoir wastewater in part of Minna Niger State. Adv Life Sci Technol 2016;51:17-25.

33. Harley JP, Prescott LM. Laboratory exercise in microbiology. New York: WBC McGraw-Hill; 1996, p.273.

34. Lutz SD. Calculating the national sanitation foundation water quality index. [cited 2020. 03. 23.] Available from: http://www.cce.iastate. edu/research/Luz/dmrwqn/water quality index calc.htm.

35. Mueller DK, Helsel DR. Nutrients in the nation's waters--too much of a good thing? US Geological Survey 1999; Circular (1136):24.

36. McNeely RN, Neimanis VP, Dwyer L. Water quality sourcebook: a guide to water quality parameters. Ottawa: Inland Waters Directorate;
2009, p. 32-70.

37. Oladeji OS. Preliminary assessment of the environmental impacts of land use patterns on groundwater quality. Glob J Environ Sci 2002; 1(1):35-42.

38. Umunnakwe JE. Development of a water quality index to assess the impact of Port Harcourt abattoir on the Woji Creek. [dissertation] Port Harcourt: Rivers State University of Science and Technology; 2007.

39. Emenike CU, Agamuthu P, Fauziah SH. Blending Bacillus sp., Lysinibacillus sp. and Rhodococcus sp. for optimal reduction of heavy metals in leachate contaminated soil. Environ Earth Sci 2016;75(26):1-8.

40. Yang T, Chen ML, Wang JH. Genetic and chemical modification of cells for selective separation and analysis of heavy metals of biological or environmental significance. Trends Anal Chem 2015,66:90-102.

41. Igiri BE, Okoduwa SIR, Idoko GO, Akabuogu EP, Adeyi AO, Ejiogu IK. Toxicity and bioremediation of heavy metals contaminated ecosystem from tannery wastewater: A Review. J Toxicol 2018;1:1-16.

42. Sannasi P, Kader J, Ismail BS, Salmijah S. Sorption of $\mathrm{Cr}(\mathrm{VI}), \mathrm{Cu}(\mathrm{II})$ and $\mathrm{Pb}(\mathrm{II})$ by growing and non-growing cells of a bacterial consortium. Bioresour Technol 2006;97(5):740-747.

43. Kader J, Sannasi P, Othman O, Ismail BS, Salmijaj S. Removal of Cr(VI) from aqueous solutions by growing and non-growing populations of environmental bacterial consortia. Glob J Environ Res 2007;1(1):1217.

44. Kuddus M, Joseph B, Ramteke PW. Production of laccase from newly isolated Pseudomonas putida and its application in bioremediation of synthetic dyes and industrial effluents. Biocatal Agric Biotechnol 2013;2(4):333-338.

45. Alvarez A, Saez JM, Costa JSD, Colin VL, Fuentes MS, Cuozzo SA, et al. Actinobacteria: Current research and perspectives for bioremediation of pesticides and heavy metals. Chemosphere 2017;166:41-62.

46. Guarino C, Spada V, Sciarrillo R. Assessment of three approaches of bioremediation (natural attenuation, land farming and bioagumentation - assisted land farming) for a petroleum hydrocarbons contaminated soil. Chemosphere 2017;170:10-16. 